\title{
Reference Wavelengths for Calibrating Prism Spectrometers
}

\author{
Earle K. Plyler, L. R. Blaine, and Matthew Nowak
}

\begin{abstract}
Standard wavelengths for calibrating infrared-prism instruments nave been measured from the absorption bands of polystyrene, 1,2,4-trichlorobenzene, and toluene. Several bands of didymium glass have been calibrated for the near-infrared region, and 27 rotational lines of the 3.3-micron band of methane have been measured.

The wavelengths fall in the region from 0.6 to 24 microns, but the greatest number are in the 3- to 6-micron region. A few bands of several other materials are also given in the wavelength tables, and 11 figures of the spectra marked with the calibrating values are included for identification.
\end{abstract}

\section{Introduction}

Two reports $[1]^{1}$ have been issued by the Bureau on calibrating wavelengths for prism spectrometers. The present report incorporates the data of the earlier reports and gives the results of recent calibrations that have been made. Other papers have been published by several laboratories [2] and their results are of value for additional calibration points. All of the standard wavelengths that have been supplied are not sufficient for calibrations needed for the range of the infrared region from 0.8 to $150 \mu$ or for the wide variety of instruments used in this region, especially with the differences in resolution obtained with different prism materials. For example, the $\mathrm{CO}$ and $\mathrm{CO}_{2}$ absorption bands between 4 and $5 \mu$, are well suited for calibration but cannot be resolved into their rotational structure by a rocksalt prism. The requirements for the calibration of a spectrometer using a rock-salt prism are much different from those of an instrument using prisms of lithium fluoride and of calcium fluoride. When the thermocouple of an instrument is replaced by a $\mathrm{PbS}$ detector, more bands that contain the rotational structure of gases can be used for calibration. Still higher resolution can be obtained by replacing the prism in the spectrometer with a grating. This usually allows the use of many bands for calibration, and if too high a precision is not required, many bands that have been measured on large grating instruments can be used.

This report does not include methods of calibration of high-resolution grating spectrometers. The use of the fringe system of a Fabry-Perot interferometer for accurate measurement of line positions observed with grating spectrometers has been previously described [3].

The calibration points listed in the present paper are primarily suited for low-resolution instruments.

\section{Method of Measurement}

A large grating spectrometer can easily measure sharp spectral lines with an error not greater than 1 part in 100,000 . This accuracy can be obtained

\footnotetext{
${ }_{1}$ Figures in brackets indicate the'literature references at the end of this paper.
}

by using standard lines of neon, argon, krypton, or xenon, in higher orders that overlap the band being measured. The standard spectral lines or the fringe svstem of a Fabry-Perot interferometer are recorded simultaneously with the absorption band being studied. The grating spectrometer and the method of calibration are described in reference [3].

The measurement of the absorption bands of liquids and solids under high resolution often reveals side bands or complex structure. The way in which the components add up to produce a seemingly sharp band on a prism instrument must be approximated by the intensity and the positions of the various components. Any band in the range 1 to $10 \mu$ that is found to have an uncertainty of more than \pm 0.003 $\mu$ is not listed as a wavelength for calibration.

Another approach in the calibration of bands is to open the slit of the grating spectrometer so that resolution equal to that of a prism spectrometer is obtained. This method reduces the high precision of measurement with the grating spectrometer, but with the wide range of resolution of different spectrometers, the band shapes could not be matched for all instruments. In order to avoid the difficulties of the low-resolution method, all the bands reported in this work have been calibrated with high-resolution spectrometers.

In the measurement of $Q$-branches of bands, considerable fine structure is observed. The Q-branch of the $\mathrm{NH}_{3}$ band at $2.999 \mu$ is shown in figure 1 . There are 30 or more separate lines and the band extends from 2.996 to $3.002 \mu$; the center on low resolution is estimated to be $2.9990 \pm 0.0005 \mu$. All of the bands measured on the grating instrument appear to be broad, and the estimate of the center for low resolution accounts for the uncertainty given with the results listed in the tables.

\subsection{Region From 0.6 to 2.6 Microns}

Although the intense infrared bands of molecules are observed at wavelengths greater than $2 \mu$, it is sometimes necessary to measure the transmission of filters and the absorption of combination bands in the near-infrared region. The atomic spectral lines are well suited for calibration in this region. The 


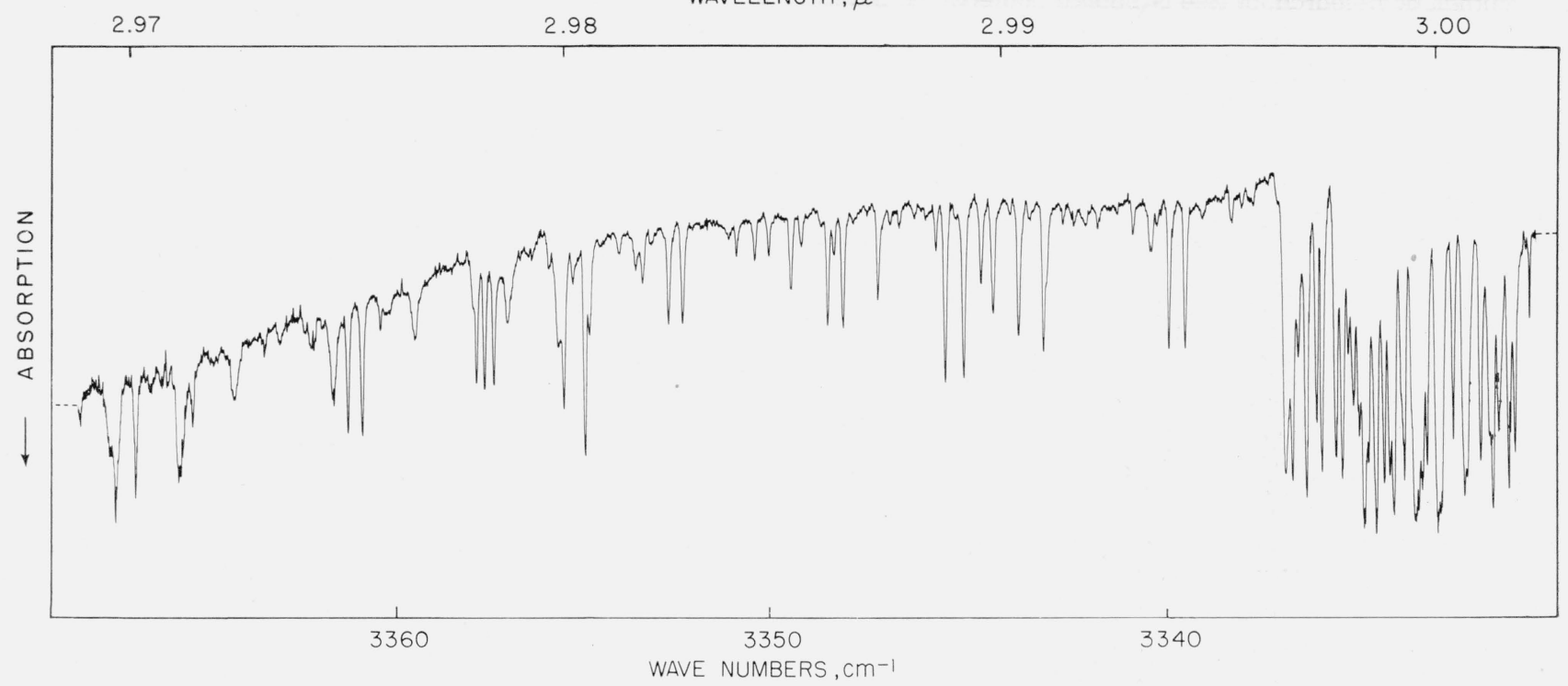

FIGURE 1. Absorption spectrum of $\mathrm{NH}_{3}$ in the Q-branch of the 2.999-micron band with high resolution.

The spectrum was observed with a meter cell at $5 \mathrm{~mm}(\mathrm{Hg})$ pressure.

spectra of mercury, neon, argon, krypton, and xenon are rich in near-infrared lines, some of which have been measured and listed in another publication [3].

The atomic spectral lines are observed in emission, but it is usually easier to use calibrating wavelengths in absorption on most infrared spectrometers.

Several bands of polystyrene, 1,2,4-trichlorobenzene, didymium glass, and carbon disulfide have been measured from 0.6 to $2.6 \mu$, and the wavelengths are listed in table 1. In addition to wavelengths, the wave numbers in vacuum, the state, the thickness, and the material are tabulated. For spec-

TABLE 1. Calibration wavelengths for prism instruments from 0.6 to $2.6 \mu$

\begin{tabular}{|c|c|c|c|c|}
\hline $\begin{array}{l}\text { Wavelength } \\
\mu \text { (air) }\end{array}$ & $\begin{array}{c}\text { Wave } \\
\text { number } \\
\text { (vacuum) }\end{array}$ & State & $\begin{array}{c}\text { Thick- } \\
\text { ness }\end{array}$ & Substance \\
\hline 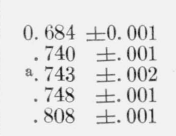 & $\begin{array}{c}\mathrm{cm}^{-1} \\
14616 \\
13510 \\
13455 \\
13365 \\
12373\end{array}$ & 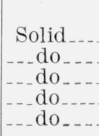 & $\begin{array}{l}m m \\
6 \\
6 \\
6 \\
6 \\
6\end{array}$ & $\begin{array}{l}\text { Didymium glass. } \\
\text { Do. } \\
\text { Do. } \\
\text { Do. } \\
\text { Do. }\end{array}$ \\
\hline $\begin{array}{ll}.880 & \pm .001 \\
1.067 & \pm .002 \\
1.220 & \pm .002 \\
1.517 & \pm .003 \\
1.681 & \pm .002\end{array}$ & $\begin{array}{r}11361 \\
9369 \\
8195 \\
6590 \\
5947\end{array}$ & 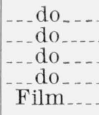 & $\begin{array}{l}6 \\
6 \\
6 \\
6 \\
0.6\end{array}$ & $\begin{array}{c}\text { Do. } \\
\text { Do. } \\
\text { Do. } \\
\text { Do. } \\
\text { Polystyrene. }\end{array}$ \\
\hline $\begin{array}{rr}1.918 & \pm .003 \\
2.144 & \pm .001 \\
\text { ь } 2.170 & \pm .002 \\
2.187 & \pm .001 \\
2.222 & \pm .002\end{array}$ & $\begin{array}{l}5212 \\
4663 \\
4607 \\
4571 \\
4499\end{array}$ & $\begin{array}{l}\text { Solid } \\
\text { Film } \\
\text { do..... } \\
\text { Liquid... }\end{array}$ & $\begin{array}{l}6 \\
0.6 \\
.6 \\
.6\end{array}$ & $\begin{array}{l}\text { Didymium glass. } \\
\text { Polystyrene. } \\
\text { Do. } \\
\text { Do. } \\
\text { Carbon disulfide. }\end{array}$ \\
\hline $\begin{array}{l}\text { 1. } 6606 \pm .0002 \\
\text { 2. } 1526 \pm .0002 \\
2.3126 \pm .0002 \\
2.4030 \pm .0002 \\
2.4374 \pm .0002\end{array}$ & $\begin{array}{l}6020.3 \\
4644.3 \\
4322.9 \\
4160.3 \\
4101.6\end{array}$ & 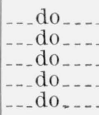 & $\begin{array}{r}0.5 \\
.5 \\
.5 \\
.5 \\
.5\end{array}$ & $\begin{array}{l}\text { 1,2,4-Trichlorobenzene. } \\
\text { Do. } \\
\text { Do. } \\
\text { Do. } \\
\text { Do. }\end{array}$ \\
\hline $\begin{array}{ll}2.494 & \pm .002 \\
2.543 & \pm .002\end{array}$ & $\begin{array}{l}4009 \\
3931\end{array}$ & -_do_. & $\begin{array}{l}.5 \\
.5\end{array}$ & $\begin{array}{l}\text { Do. } \\
\text { Do. }\end{array}$ \\
\hline
\end{tabular}

s A verage value of the maxima for 0.740 and $0.748 \mu$.

b Principal band observed with prism spectrometer. trometers that are able to resolve the rotational structure of the $\mathrm{CO}$ band at $2.34 \mu$, there are provided about 50 lines from 2.3 to $2.5 \mu$ that are known to a high accuracy [4]. Table 1 is essentially the same as that given previously [1].

The observed spectrum of didymium glass, 1,2,4-trichlorobenzene, and polystyrene with low resolution are shown in figures 2,3 , and 4 .

\subsection{Region From 2.6 to 22 Microns}

The region from 2.6 to $15 \mu$ is employed for analysis of many compounds. As there are many automatic instruments in use that give the wavelength readings directly, it is important to have a

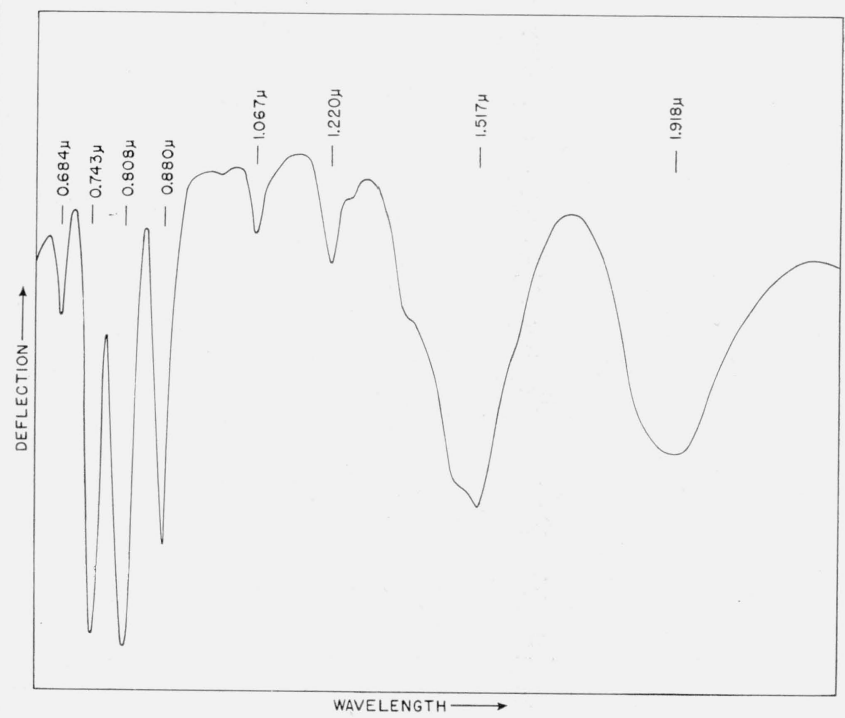

Figure 2. Absorption spectrum of didymium glass, 6 millimeters thick, in the region from 0.6 to 2 microns. 


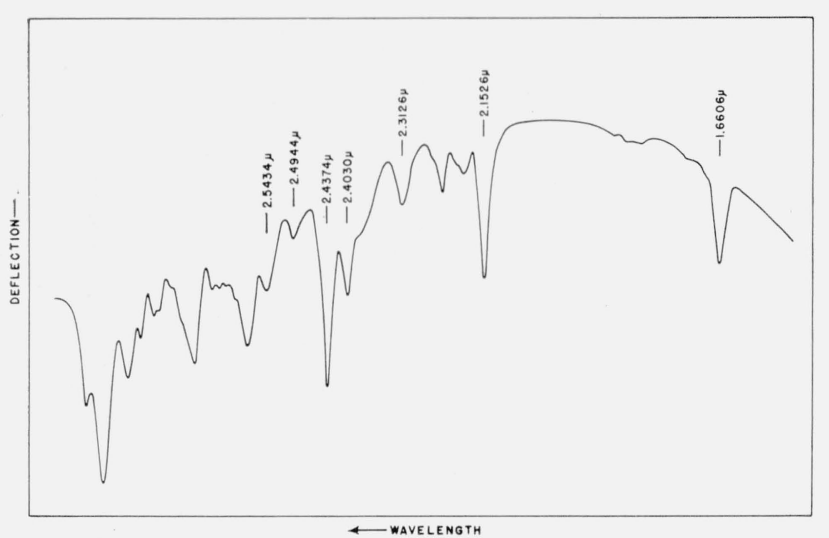

FIGURE 3. Near-infrared spectrum of 1,2,4-trichlorobenzene for a cell thickness of 0.5 millimeter.

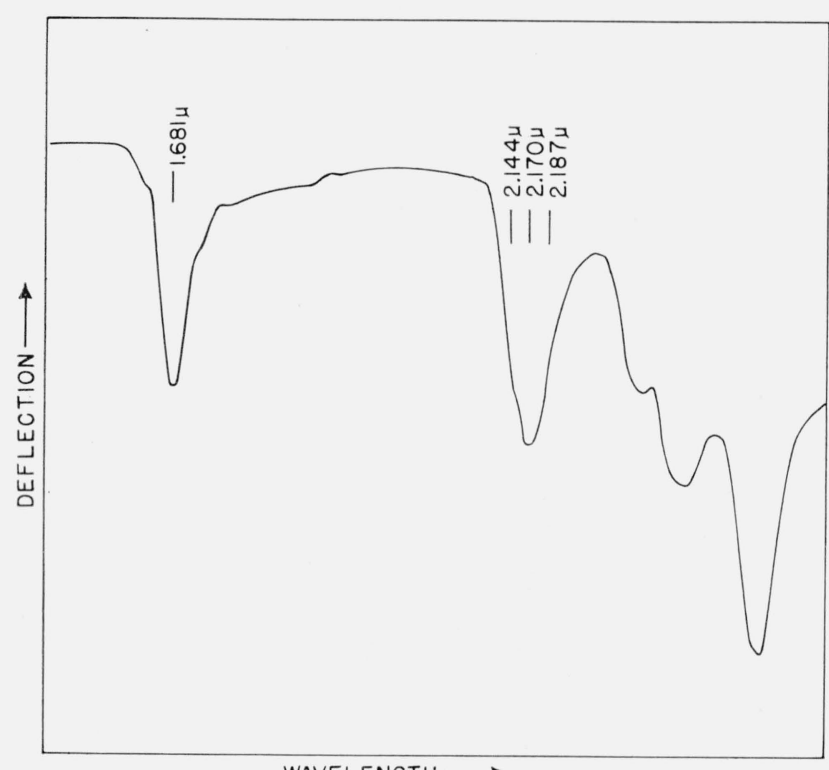

Figure 4. Near-infrared spectrum of polystyrene for a thickness of 0.6 millimeter.

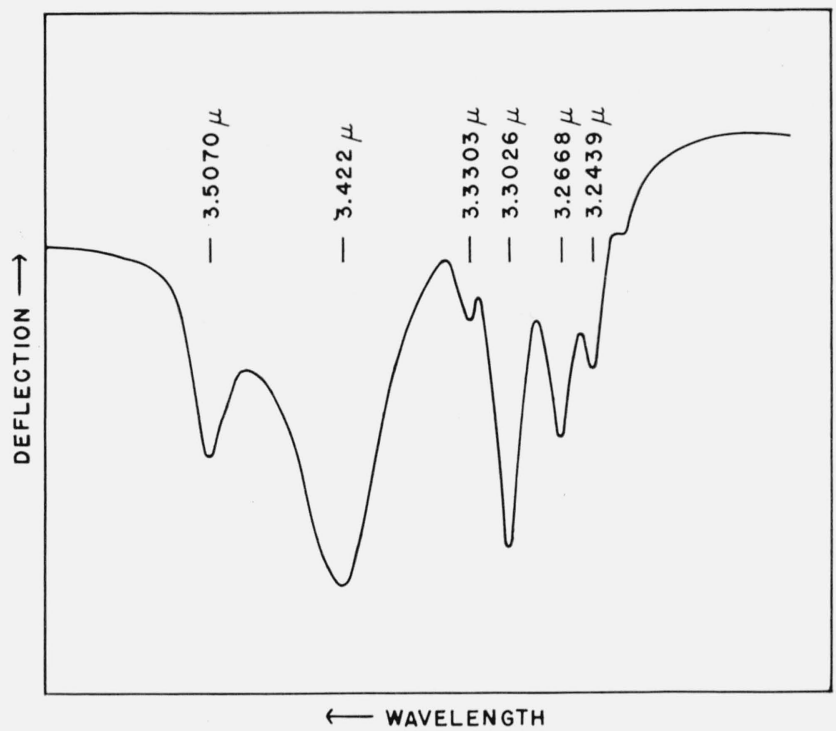

FIGURE 5. Infrared absorption bands of polystyrene in the region of 3.4 microns for a film about 25 microns thick, as observed with a lithium fluoride prism.

few substances that can be used to check the calibration of the instrument. A number of absorption bands have been measured for this region. The largest number of bands have been selected from the spectrum of polystyrene, toluene, and 1,2,4-trichlorobenzene.

Polystyrene films are easily made, and the spectrum is suitable for a check of the instrument. Several of the bands have been remeasured, and the wavelengths check closely with the previous values [1], and an estimate of the accuracy of the wavelengths has been given.

Figure 5 shows the bands in the $3.4-\mu$ region of polystyrene as measured with a LiF prism.

Figure 6 is a record of the spectrum from 2 to $15 \mu$, measured with a rock-salt prism. When the

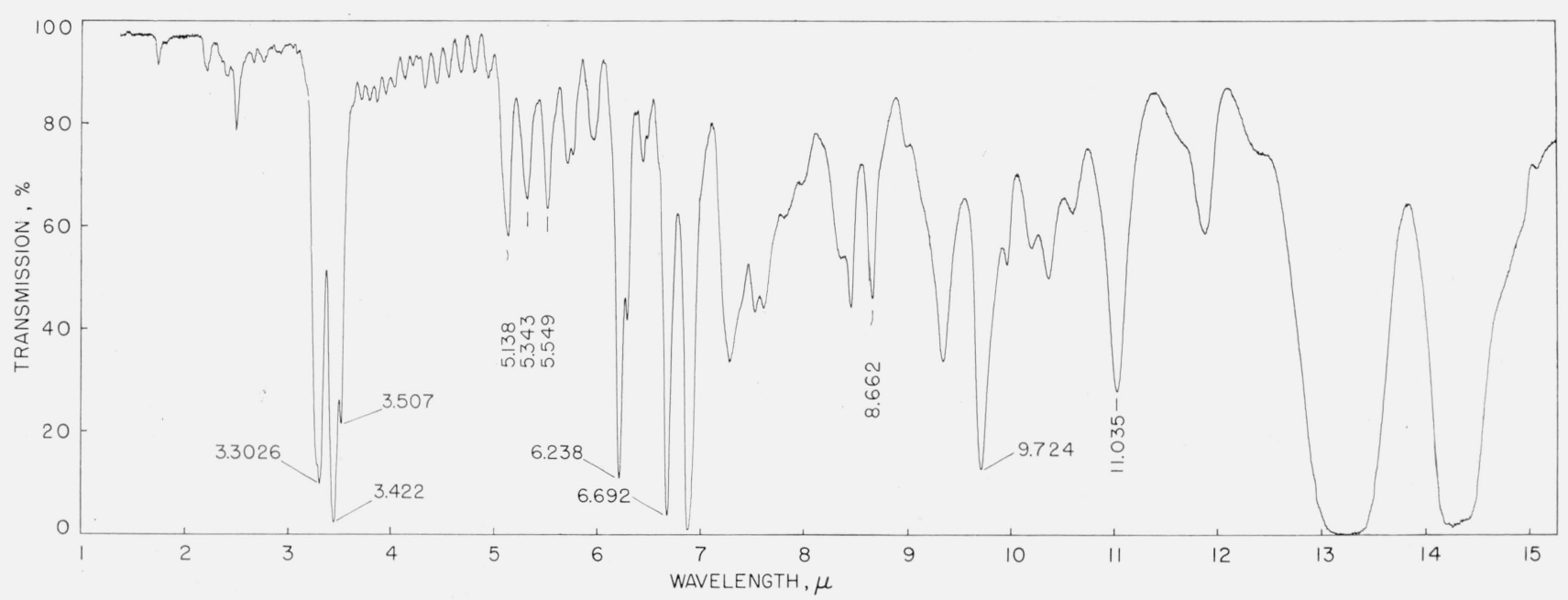

FIGURE 6. Infrared absorption spectrum, from 2 to 15 microns, of a 50-micron film of polystyrene measured with a rock-salt prism instrument. 


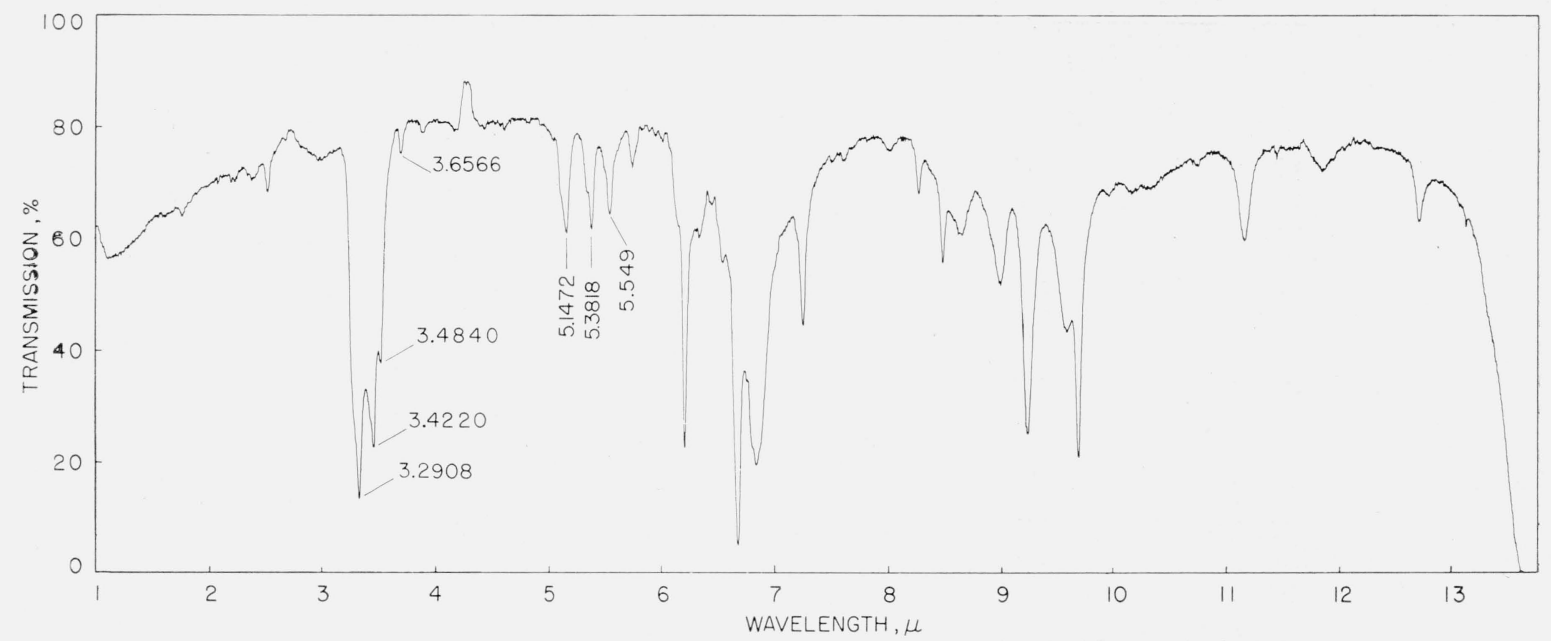

FIGURE 7. Infrared spectrum of toluene from 2 to 15 microns,"as"observed with a rock-salt prism.

Cell thickness was $0.05 \mathrm{~mm}$.

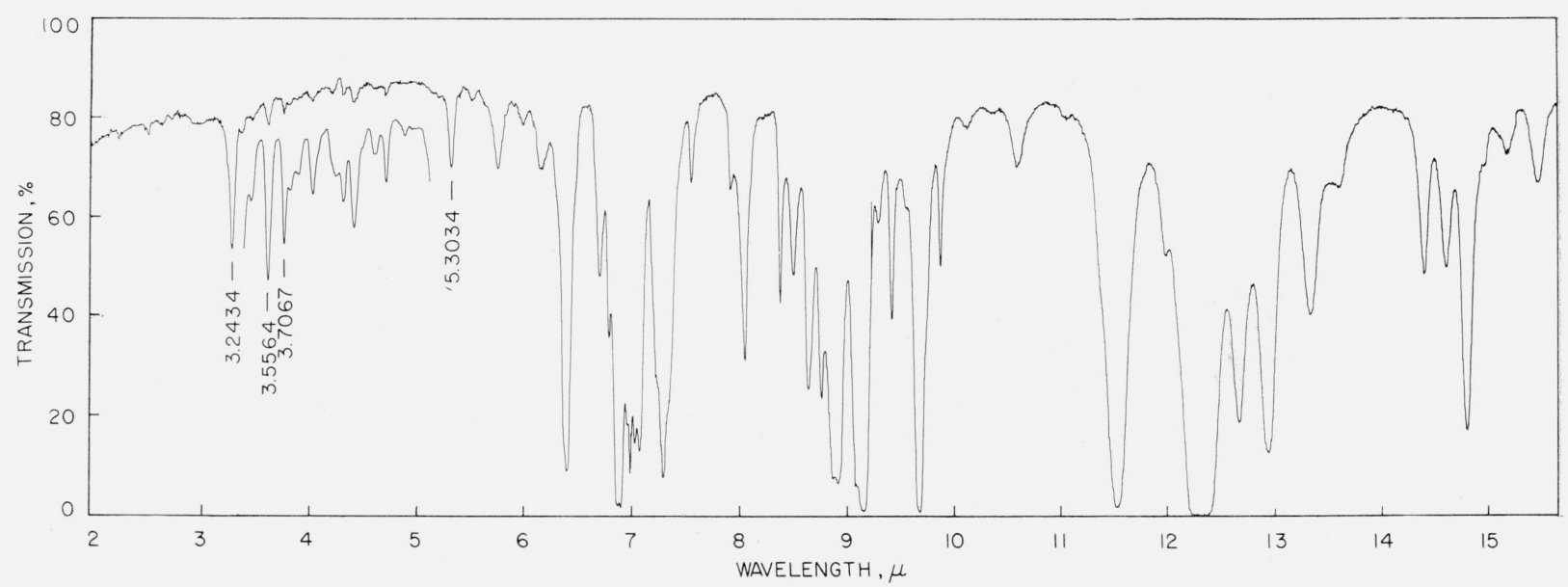

FIGURE 8. Spectrum of 1,2,4-trichlorobenzene from 2 to 15 microns, as observed with a rock-salt prism.

Cell was $0.025 \mathrm{~mm}$, and the insert spectrum from 3.5 to $5 \mu$ was measured with a cell of $0.2 \mathrm{~mm}$.

surfaces of the film are parallel a number of interference fringes appear in the spectrum. The fringes are of low intensity and usually do not change the wavelength of the absorption bands.

Figure 7 represents the spectrum of toluene. Some of the bands that have been measured fall close to the calibrated bands of polystyrene and of 1,2,4-trichlorobenzene (fig. 8). Any one of these substances would be sufficient for checking any changes that may occur in a spectrometer with a wavelength scale.

The absorption spectrum of Corning fused quartz has a strong band at $2.7 \mu$. This band has been measured for a calibration point in this region, and the center occurs at $2.735 \mu$. The absorption spectrum is shown for a thickness of $0.7 \mathrm{~mm}$ in figure 9 . With a thinner sample the band is not as broad and is less absorbing. This band is produced by occluded water and it is not present in all types of fused quartz.

Other materials with absorption bands, listed in table 2 , are carbon dioxide, carbon disulfide, methyl-

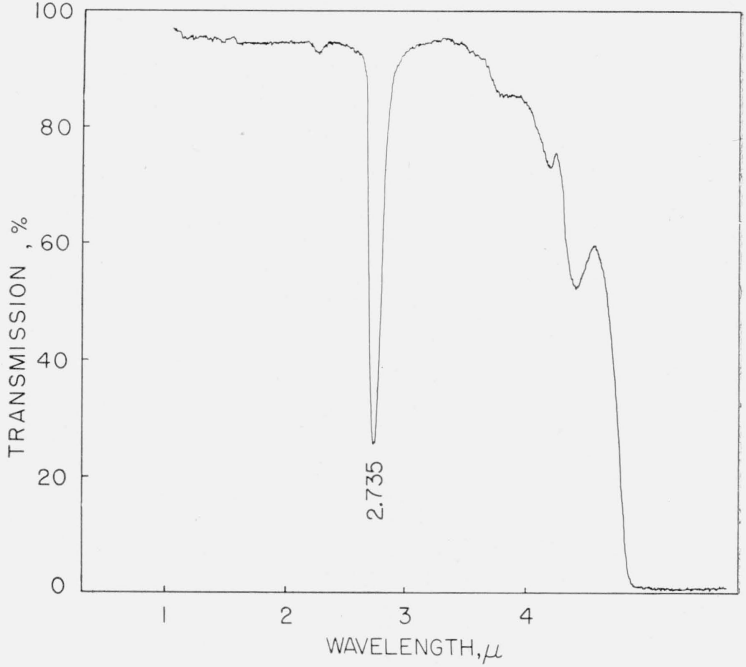

FiguRE 9. Band at 2.735 microns in Corning fused silica for 0.7-millimeter thickness. 
TABLE 2. Calibrating wavelengths from 3 to $24 \mu$

\begin{tabular}{|c|c|c|c|c|}
\hline $\begin{array}{l}\text { Wavelength } \\
\text { (air) }\end{array}$ & $\begin{array}{l}\text { Wave } \\
\text { num- } \\
\text { ber } \\
\text { (vac- } \\
\text { uum) }\end{array}$ & State & Description & Substance \\
\hline $\begin{array}{l}{ }^{\mu} \\
\text { 2. } 735{ }^{ \pm} \pm 0.0002 \\
2.9990 \pm .0005\end{array}$ & $\begin{array}{c}c m^{-1} \\
3655.3 \\
3333.5\end{array}$ & $\begin{array}{l}\text { Solid.... } \\
\text { Gas..... }\end{array}$ & \multirow{3}{*}{$\begin{array}{l}0.7 \mathrm{~mm} \text { thick } \\
1-\mathrm{m} \text { cell, } 5 \mathrm{~mm} \\
(\mathrm{Hg}) . \\
5.0-\mathrm{cm} \text { cell, } 10 \\
\mathrm{~cm}(\mathrm{Hg}) \text {. } \\
25-\mu \text { film }\end{array}$} & \multirow{3}{*}{$\begin{array}{l}\text { Quartz. } \\
\mathrm{NH}_{3} . \\
\text { Methane. } \\
\text { Polystyrene. } \\
\text { Do. }\end{array}$} \\
\hline 3. 3101 & 3020.2 & .... do & & \\
\hline $\begin{array}{l}\text { 3. } 2204 \\
\text { 3. } 2439 \pm .0002\end{array}$ & $\begin{array}{l}3104.4 \\
3081.9\end{array}$ & \begin{tabular}{|} 
Solid \\
............
\end{tabular} & & \\
\hline $\begin{array}{l}\text { 3. } 2668 \pm .0002 \\
\text { 3. } 3026 \pm .0001 \\
\text { 3. } 3303 \pm .0001 \\
\text { 3. } 422 \pm .001 \\
\text { 3. } 5070 \pm .0005\end{array}$ & $\begin{array}{l}3060.3 \\
3027.1 \\
3001.9 \\
2921.5 \\
2850.7\end{array}$ & \begin{tabular}{l}
$\ldots$ do \\
$\ldots$ do \\
\hdashline \\
\hdashline do
\end{tabular} & 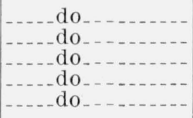 & $\begin{array}{l}\text { Do. } \\
\text { Do. } \\
\text { Do. } \\
\text { Do. } \\
\text { Do. }\end{array}$ \\
\hline $\begin{array}{ll}5.138 & \pm .005 \\
5.343 & \pm .003 \\
5.549 & \pm .002 \\
6.238 & \\
6.692 & \end{array}$ & $\begin{array}{l}1945.8 \\
1871.1 \\
1801.6 \\
1602.7 \\
1493.9\end{array}$ & 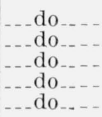 & \begin{tabular}{l}
$50-\mu$ film \\
\hdashline do \\
\hdashline \\
\hdashline
\end{tabular} & $\begin{array}{l}\text { Do. } \\
\text { Do. } \\
\text { Do. } \\
\text { Do. } \\
\text { Do. }\end{array}$ \\
\hline 8. 662 & 1154. 2 & _._do do..- & ....do_. & Do. \\
\hline $\begin{array}{r}9.724 \\
11.035\end{array}$ & $\begin{array}{r}1028.1 \\
906.0\end{array}$ & _..-do do... & .....do_- & $\begin{array}{l}\text { Do. } \\
\text { Do. }\end{array}$ \\
\hline $\begin{array}{l}\text { 3. } 2393 \pm .0006 \\
3.2908 \pm .0003\end{array}$ & $\begin{array}{l}3086.2 \\
3038.0\end{array}$ & $\begin{array}{l}\text { Liquid. } \\
\text { do }\end{array}$ & $0.05-\mathrm{mm}$ cell & $\begin{array}{c}\text { Toluene. } \\
\text { Do. }\end{array}$ \\
\hline $3.4220 \pm .0009$ & 2921.5 & ..._do... & ......do_. & Do. \\
\hline $3.4840 \pm .0004$ & 2869.5 & ...do do.. & do & Do. \\
\hline 3. $6566 \pm .0002$ & 2734.0 & ... do & ..... do & Do. \\
\hline $\begin{array}{l}5.1472 \pm .0007 \\
5.3818 \pm .0006\end{array}$ & $\begin{array}{l}1942.3 \\
1857.6\end{array}$ & _._do do... & [.....do_- & $\begin{array}{l}\text { Do. } \\
\text { Do. }\end{array}$ \\
\hline 5. $549 \quad \pm .002$ & 1801.6 & .._do do... & ......do. & Do. \\
\hline $\begin{array}{l}21.52 \\
3.2434 \pm .0003\end{array}$ & $\begin{array}{r}464.6 \\
3082.4\end{array}$ & -..do do..... & $0.025-\mathrm{mm}$ cell & $\begin{array}{l}\text { Do. } \\
\text { 1,2,4-Trichloro- }\end{array}$ \\
\hline $\begin{array}{l}3.5564 \pm .0002 \\
3.7067 \pm .0002\end{array}$ & $\begin{array}{l}2811.1 \\
2697.1\end{array}$ & _..do do & .....do... & $\begin{array}{l}\text { Do. } \\
\text { Do. }\end{array}$ \\
\hline 5. $3034 \pm .0025$ & 1885.1 & ... do do... & ...... do_. & Do. \\
\hline 17.40 & 574.6 & -...do_... & .....-do_- & Do. \\
\hline $\begin{array}{l}\begin{array}{l}18.16 \\
21.80\end{array}\end{array}$ & $\begin{array}{l}550.5 \\
458.6\end{array}$ & - do do & do & $\begin{array}{l}\text { Do. } \\
\text { Do. }\end{array}$ \\
\hline 22.76 & 439.3 & ... do & do & Do. \\
\hline 20.56 & 486.3 & ... do & 0.05 -mm cell (sat. & 1,2,3-Trichloro- \\
\hline $\begin{array}{l}\text { 2. } 7144 \\
\text { 4. } 866\end{array}$ & $\begin{array}{l}3683.0 \\
2054.5\end{array}$ & Vapor... & 5.0-cm cell & $\begin{array}{l}\text { Methanol. } \\
\text { Do. }\end{array}$ \\
\hline 9.672 & 1033.6 & do & do & Do. \\
\hline 4. 258 & 2347.9 & Gas_. & Atmospheric_ & Carbon dioxide. \\
\hline $\begin{array}{l}13.883 \\
14.98\end{array}$ & $\begin{array}{l}720.1 \\
667.4\end{array}$ & _._do do_-_ & ......do_. & $\begin{array}{l}\text { Do. } \\
\text { Do. }\end{array}$ \\
\hline 7.268 & 1375.5 & Liquid. & $0.05-\mathrm{mm}$ cell & Methylcyclo- \\
\hline $\begin{array}{l}11.475 \\
11.862\end{array}$ & $\begin{array}{l}871.2 \\
842.8\end{array}$ & _._do do_._. & _-_do & $\begin{array}{l}\text { Do. } \\
\text { Do. }\end{array}$ \\
\hline 23.85 & 419. 2 & Vapor_._ & Atmospheric.. & Water. \\
\hline
\end{tabular}

cyclohexane, and methanol. 'The wavelengths of the bands of methanol have not been remeasured but are taken from the work of Borden and Barker [5].

The spectrum of 1,2,4-trichlorobenzene has been measured in the region from 14 to $24 \mu$, figure 10 . The absorption bands at $17.40,18.16$, and $21.80 \mu$ were measured on a grating spectrometer. The broad band at $22.76 \mu$ was measured on a prism spectrometer and is probably accurate to $\pm 0.02 \mu$.

The absorption spectra of many gases have been measured and would be useful for calibration. If the prism spectrometer cannot resolve the spectra into the rotational lines, they should not be used. The atmospheric-water-vapor lines in the vibrational rotational band are not properly resolved with prism instruments, but the pure rotation spectrum from 20 to $150 \mu$ is well suited for calibration. These lines have been measured by Randall, Dennison, Ginsburg, and Weber [6], and their article lists the observed wavelengths.

The spectrum of methane at $3.3 \mu$ contains many rotational lines of the $P$ - and $R$-branches, which are spaced at intervals of about $10 \mathrm{~cm}^{-1}$. This band was recently measured with high resolution, and many of the lines were found to have several components. The spectrum was then recorded with a resolution of $0.3 \mathrm{~cm}^{-1}$, and the center of the components of a line was estimated by comparing the results with the high-resolution measurements. A photograph of the low-resolution trace is shown in figure 11, and the positions of lines are given in table 3. Where partial resolution is obtained in some lines of the $P$-branch, the wavelength and wave number are listed as applying to the strongest component.

The absorption lines observed between the methane lines are part of the $2 v_{2}$ band of atmospheric water vapor. The values of the wave numbers of the lines reported in this table are probably accurate to $\pm 0.05 \mathrm{~cm}^{-1}$, but a more precise table of wave numbers, including all the components of the lines, will be listed in another paper.

Hydrogen chloride and hydrogen bromide also have many rotational lines in their spectra that fall

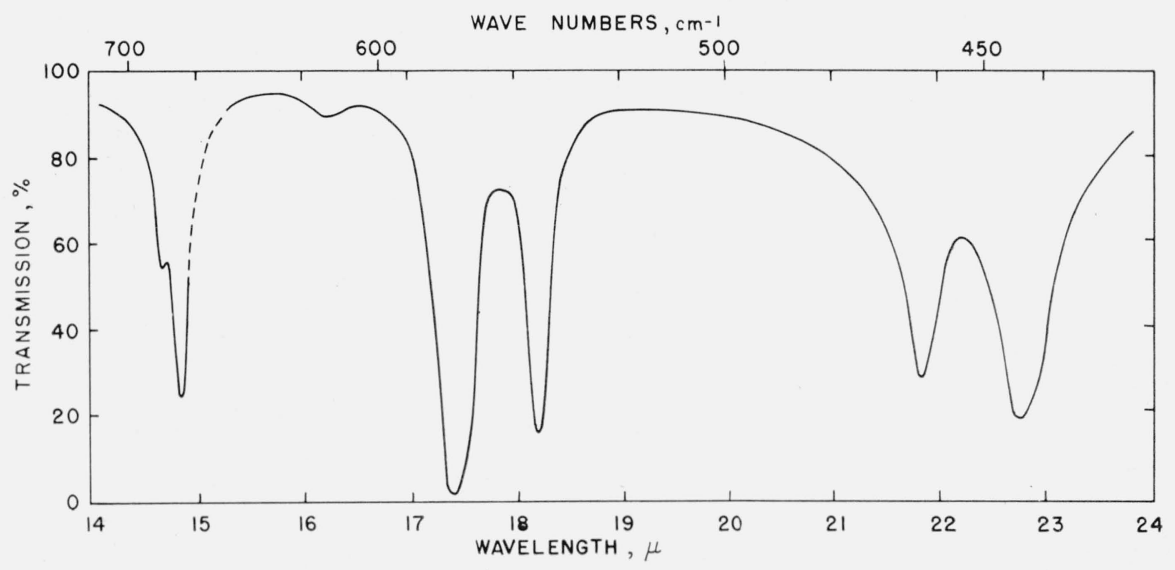

Figure 10. Spectrum of 1,2,4-trichlorobenzene from 14 to 24 microns, as observed with a $\mathrm{KBr}$ prism. 


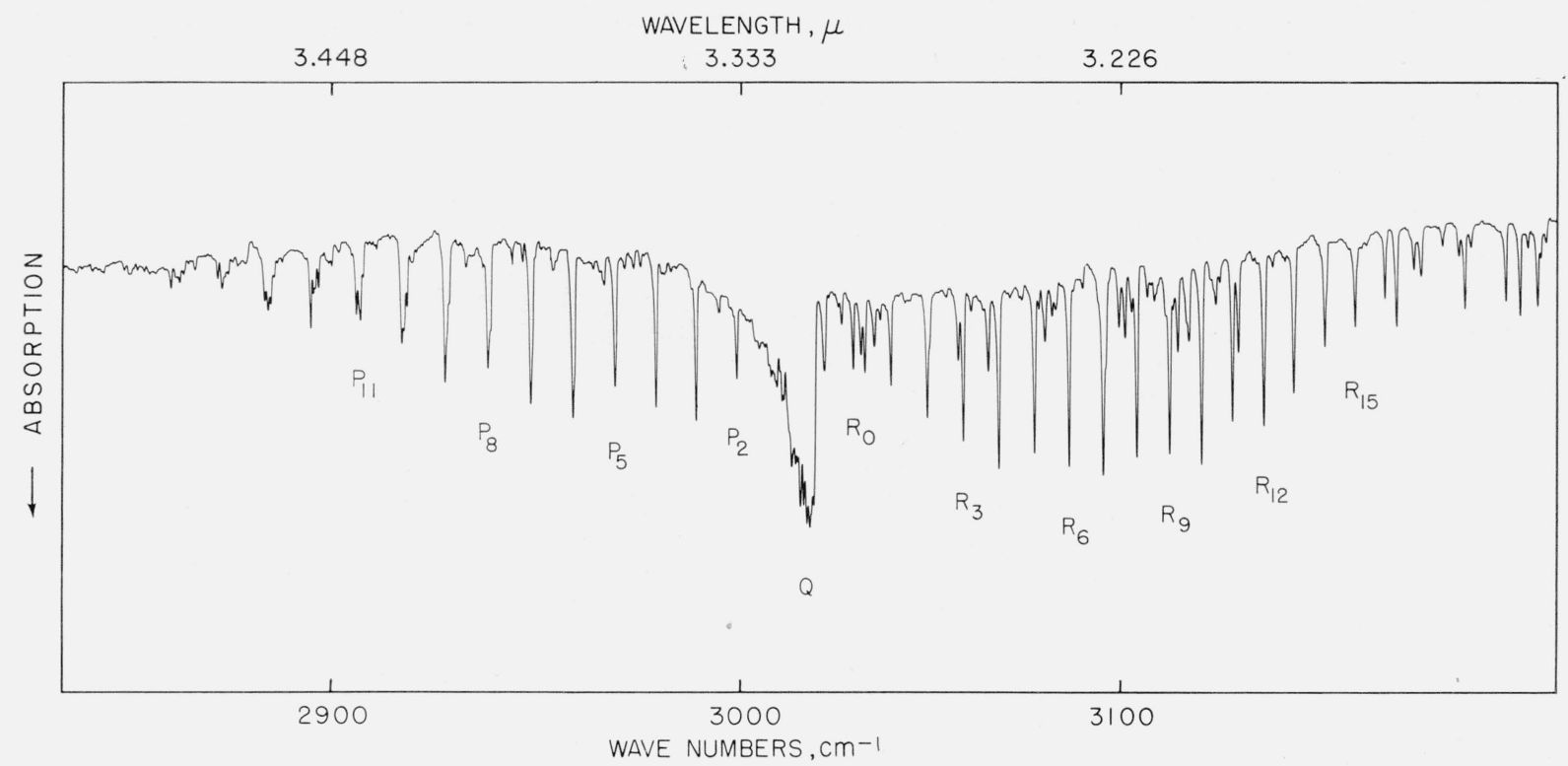

FIgURE 11. The 3.3-micron band of methane with medium resolution.

Cell length, $5 \mathrm{~cm}$; pressure, $10 \mathrm{~cm}(\mathrm{Hg})$.

TABLE 3. Rotational lines of methane in the 3.3- $\mu$ band

\begin{tabular}{|c|c|c|}
\hline Line & $\begin{array}{l}\text { Wave- } \\
\text { length } \\
\text { (air) }\end{array}$ & $\begin{array}{c}\text { Wave } \\
\text { number } \\
\text { (vacuum) }\end{array}$ \\
\hline $\begin{array}{l}P_{12} \\
P_{11} \\
P_{10} \\
P_{9} \\
P_{8}\end{array}$ & $\begin{array}{c}\mu \\
3.45309 \\
3.43937 \\
3.42801 \\
3.41571 \\
3.40352\end{array}$ & $\begin{array}{c}c m^{-1} \\
2895.18 \\
2906.72 \\
2916.36 \\
2926.86 \\
2937.34\end{array}$ \\
\hline $\begin{array}{l}P_{7} \\
P_{6} \\
P_{5} \\
P_{4} \\
P_{3}\end{array}$ & $\begin{array}{l}\text { 3. } 39131 \\
\text { 3. } 37952 \\
\text { 3. } 36760 \\
\text { 3. } 35592 \\
\text { 3. } 34552\end{array}$ & $\begin{array}{l}2947.92 \\
2958.20 \\
2968.67 \\
2979.00 \\
2988.27\end{array}$ \\
\hline $\begin{array}{l}P_{2} \\
R_{0} \\
R_{1} \\
R_{2} \\
R_{3}\end{array}$ & $\begin{array}{l}\text { 3. } 33343 \\
\text { 3. } 30070 \\
\text { 3. } 29012 \\
\text { 3. } 27969 \\
\text { 3. } 26945\end{array}$ & $\begin{array}{l}2999.10 \\
3028.84 \\
3038.58 \\
3048.25 \\
3057.79\end{array}$ \\
\hline $\begin{array}{l}R_{4} \\
R_{5} \\
R_{6} \\
R_{7} \\
R_{8}\end{array}$ & $\begin{array}{l}\text { 3. } 25932 \\
\text { 3. } 24932 \\
\text { 3. } 23955 \\
\text { 3. } 22992 \\
\text { 3. } 22041\end{array}$ & $\begin{array}{l}\text { 3067. } 30 \\
\text { 3076. } 74 \\
\text { 3086. } 02 \\
\text { 3095. } 22 \\
3104.36\end{array}$ \\
\hline $\begin{array}{l}R_{9} \\
R_{10} \\
R_{11} \\
R_{12} \\
R_{13}\end{array}$ & $\begin{array}{l}\text { 3. } 21103 \\
\text { 3. } 20174 \\
3.19261 \\
\text { 3. } 18365 \\
\text { 3. } 17480\end{array}$ & $\begin{array}{l}3113.42 \\
3122.46 \\
3131.39 \\
3140.20 \\
3148.95\end{array}$ \\
\hline $\begin{array}{l}R_{14} \\
R_{15}\end{array}$ & $\begin{array}{l}3.16610 \\
3.15751\end{array}$ & $\begin{array}{l}3157.61 \\
3166.20\end{array}$ \\
\hline
\end{tabular}

in the region from 3 to $5 \mu$. These gases have recently been measured by Thompson and his co-workers [7] on a grating spectrometer, and the positions of the lines are listed in his papers.

The absorption bands listed in tables 1 and 2 are selected for the calibration of spectrometers of low or medium resolution. The calibration of highresolution instruments would require atomic-spectral lines or the rotational lines of the bands of gases.

Additional calibrating wavelengths can be obtained by using the bands of methane and ammonia, which almost completely cover the range from 6 to $12 \mu$. The wavelengths for these lines have not been listed because no high-precision measurements of these spectra are available, but the current measurements in the literature are sufficiently accurate for the calibration of prism spectrometers.

\section{References}

[1] Earle K. Plyler and C. Wilber Peters, J. Research NBS 45, 462 (1950) RP2159. Nicolo Acquista and Earle K. Plyler, J. Research NBS 49, 13 (1952) RP2338.

[2] R. A. Oetjen, Chao-Lou Kao, add H. M. Randall, Rev. Sci. Instr. 13, 515 (1942). A. R. Downie, M. C. Magoon, Thomas Purcell, and Bryce Crawford, Jr., J. Opt. Soc. Am. 43, 941 (1953). L. H. Jones, J. Chem. Phys. 24, 1250 (1956).

[3] Earle K. Plyler, L. R. Blaine, and Eugene D. Tidwell, J. Research NBS 55, 279 (1955) RP2630.

[4] Earle K. Plyler, W. S. Benedict, and Shirleigh Silverman, J. Chem. Phys. 20, 175 (1952).

[5] Avis Borden and E. F. Barker, J. Chem. Phys. 6, 553 (1938)

[6] H. M. Randall, D. M. Dennison, N. Ginsburg, and L. R. Weber, Phys. Rev. 52, 160 (1937).

[7] H. W. Thompson, R. L. Williams, and H. J. Callomon, Spectrochim Acta 5, 313 (1952). I. M. Mills, H. W' Thompson, and R. L. Williams, Proc. Roy. Soc. [A] 218, 29 (1953).

Washington, November 15, 1956. 